Journal of Engineering and Applied Sciences 14 (24): 9592-9597, 2019

ISSN: 1816-949X

(C) Medwell Journals, 2019

\title{
Effect of Temperature on Effective Moisture Diffusivity in Paddy Drying with Dehumidified Air
}

\author{
Mohamad Djaeni, Fauzan Irfandy and Febiani Dwi Utari \\ Department of Chemical Engineering, Faculty of Engineering, Diponegoro University, \\ 50275 Semarang, SH, Tembalang, J1 Prof. H. Soedarto, Indonesia \\ moh.djaeni@live.undip.ac.id
}

\begin{abstract}
This research discusses the effective moisture diffusivity on paddy drying with air dehumidified by zeolite. The paddy with an initial moisture content of $22 \%$ (wet basis) was dried in fluidized bed dryer at different temperature ranging $40-60^{\circ} \mathrm{C}$. As a response, the moisture content in paddy was observed every $10 \mathrm{~min}$ for operational drying time $90 \mathrm{~min}$. In doing so, a mathematical model was developed to predict the effective moisture diffusivity that was validated with average moisture content from the experiment. Result showed that the effective moisture diffusivity of paddy dried with zeolite was higher than that of without zeolite. The model also can fit with the experiment and be able to describe the moisture distribution accurately. Moreover, the quality of paddy based on proximate analysis during the drying process was acceptable and comparable with the quality of paddy dried without zeolite.
\end{abstract}

Key words: Paddy drying, effective moisture diffusivity, zeolite, drying time, accurately, distribution

\section{INTRODUCTION}

One of the major economic crops that produces and consumes to provide food supply in several countries is paddy. The major operations for paddy processing involve soaking, parboiling or steaming, drying and milling. The quality of post harvested paddy can be kept by the drying process. The drying process by reduction of moisture content can be an option to prolong the shelf life of food product. The shelf life of paddy can be extended until 18 month when the maximum moisture content is 14\% (Morrison et al., 2016).

Today, there are two methods of paddy drying: direct sunlight and conventional dryer. Because of its simplicity and low energy cost, the direct sunlight drying is commonly used by farmers (Djaeni et al., 2014). Conventional dryers such as a fluidized bed have more advantages such as controlable process, uniform moisture content of the product, shorter operational time because of high surface area, no dependency on the climate, low product contamination, low initial cost and small space usage because of small equipment (Djaeni et al., 2015; Kiranoudis et al., 1996).

Mathematical model is the important aspect to characterize drying process in paddy, since, it is useful to find the favorable drying condition as well as effective drying time. The fundamental of drying model and simulation can predict the important paramaters for the drying process (Gunhan et al., 2005). Several paddy drying can be described using two term, page or modified page models (Omid et al., 2006; Utari et al., 2018; Manikantan et al., 2014; Laohavanich and Wongpichet, 2008). The models were proper to represent thin layer drying in which useful to determine drying time. Thin layer drying is the simple model that assumes the sample as the one layer or slices particle with uniform temperature distribution (Erbay and Icier, 2010). In paddy drying there are two different layers, the outer and the inner layer with different characteristics. In this study, the mathematical model was developed to expose the paddy layers characteristics. The finding of this study will give new approach in paddy drying characterization.

The aim of this study was to evaluate the effect of temperature and air dehumidified with zeolite in paddy drying. A mathematical model was developed to estimate effective moisture diffusivity and predict moisture content distribution in paddy layer during the drying. The model was fitted with experimental data in order to be accurate to predict the drying time of paddy at various air condition. Beside that the proximates were evaluated after the completion of the drying process.

Corresponding Author: Mohamad Djaeni, Department of Chemical Engineering, Faculty of Engineering, Diponegoro University, 50275 Semarang, SH, Tembalang, Jl Prof. H. Soedarto, Indonesia, moh.djaeni@live.undip.ac.id 


\section{MATERIALS AND METHODS}

\section{Paddy drying}

Material: Paddy was obtained from a local farmer in Semarang at the initial moisture content about $22 \%(\mathrm{w} / \mathrm{w})$ or 0.28 (dry basis, gr water per gram dry paddy). The zeolite 3A (provided by Zeochem, Switzerland) was used as an adsorbent to dehumidify ambient air as drying

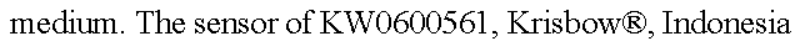
was used for measuring air temperature anda relative humidity. The air velocity was measured by KRISBOW instruments Anemometer KW06562. The water content in paddy was analyzed using a grain moisture meter G-Won GMK-303RS.

Experimental set-up: The paddy drying system was designed as a fluidized bed dryer (Fig. 1). The dryer was equipped with a blower to deliver air for the fluidization process. Initially, ambient air at a Relative Humidity $(\mathrm{RH})$ of $70-80 \%$, air veolcity of $5.51 \mathrm{msec}^{-1}$ and temperature about $28-31{ }^{\circ} \mathrm{C}$ was contacted with the zeolite column to reduce the moisture content. The dry air was then heated up to dryer temperature (supposed at $40^{\circ} \mathrm{C}$ ). The $100 \mathrm{~g}$ of paddy with initial moisture content about $22 \%(\mathrm{w} / \mathrm{w})$ or 0.28 (dry basis) was dried with the air. Every $10 \mathrm{~min}$, the moisture content in the paddy was observed using a grain moisture meter G-Won GMK-303RS for $90 \mathrm{~min}$. After the drying process, the proximates in paddy were analyzed including protein, carbohydrat and fat. The process was repeated for the inlet air temperature of 50 and $60^{\circ} \mathrm{C}$.

Moisture ratio calculation: The equilibrium moisture content of paddy was estimated using the modified Henderson Model (Thompson et al., 1968):

$$
\begin{gathered}
C_{E, w b}=\left[\operatorname{In}\left(1-H_{R}\right) /\left(-K\left(T_{C}+M\right)\right)\right]^{1 / \mathrm{N}} \\
C_{E}=\frac{C_{E, w b}}{1-C_{E, w b}}
\end{gathered}
$$

Where:

$\mathrm{C}_{\mathrm{E}, \mathrm{wb}}=$ The equilibrium moisture Content of paddy in wet basis (\%)

$\mathrm{C}_{\mathrm{E}}=$ The equilibrium moisture Content of paddy in dry basis (gr water per gram dry paddy)

$\mathrm{H}_{\mathrm{R}}=$ The relative Humidity (decimal)

$\mathrm{T}_{\mathrm{C}}=$ The air Temperature $(\mathrm{C})$ with $\mathrm{K}, \mathrm{L}$ and $\mathrm{M}$ values as follows (Nguyen et al., 2016):

$$
\begin{aligned}
& \mathrm{K}=1.9187 \times 10^{-5} \\
& \mathrm{~L}=2.4451 \\
& \mathrm{M}=51.161
\end{aligned}
$$

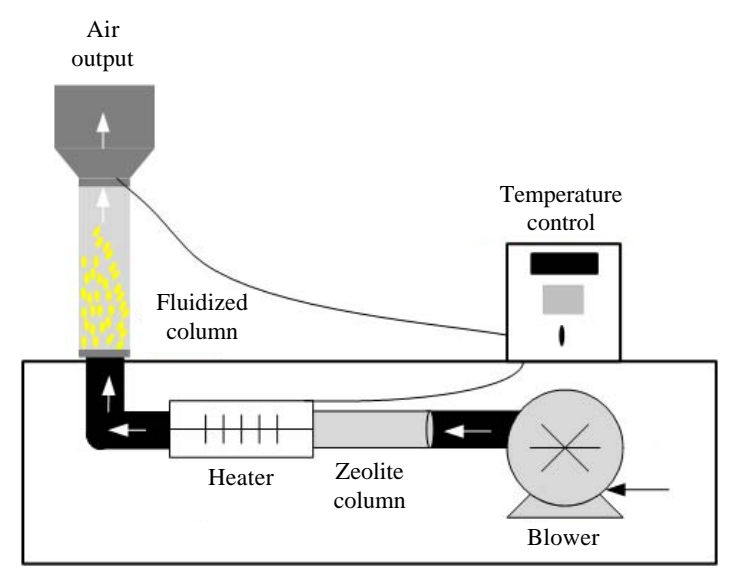

Fig. 1: The fluidized bed drying equipment according to (Djaeni et al., 2013) with modification

The moisture ratio during the drying process can be estimated based on the moisture content observation every sampling time. The following equation was used (Nguyen et al., 2016):

$$
M R=\frac{\left(C-C_{E}\right)}{\left(C_{0}-C_{E}\right)}
$$

Where:

$\mathrm{C}=$ The moisture content at time $\mathrm{t}$ min (gr water per gram dry paddy)

$\mathrm{C}_{0}=$ The initial oisture content (gr water per gram dry paddy) at the $0 \mathrm{~min}$

Mathematical model: A mathematical model was developed to predict the effective moisture diffusivity $\left(D_{\text {eff }}\right)$, constant rate of the drying $(\mathrm{k})$ and the moisture mass distribution in paddy drying. The model was derived based on phenomena as illustrated in Fig. 2. Based on Fig. 2, the differential equation for cylindric can be applied (Bird et al., 2007).

The following assumptions was used before developing the models: the grain material was a cylinder (Fig. 2), the effective moisture diffusivity and the density of water in solid were constant, the initial water content was uniform in all sections of paddy grain, the water diffused in the radial direction, the air velocity was uniform in all sections of the drying column, the heater temperature was uniform in all sections of the drying column, the air and paddy mixture was homogenous system and one paddy grain represented all dried paddy grain materials. The models can be represented in Eq. 4-9:

$$
\frac{\partial \mathrm{C}}{\partial \mathrm{t}}=\mathrm{D}_{\text {eff }}\left(\frac{1}{\mathrm{r}} \frac{\partial}{\partial \mathrm{r}}\left(\mathrm{r} \frac{\partial \mathrm{C}}{\partial \mathrm{r}}\right)+\frac{1}{\mathrm{r}^{2}} \frac{\partial^{2} \mathrm{C}}{\partial \theta^{2}}+\frac{\partial^{2} \mathrm{C}}{\partial \mathrm{z}^{2}}\right)
$$




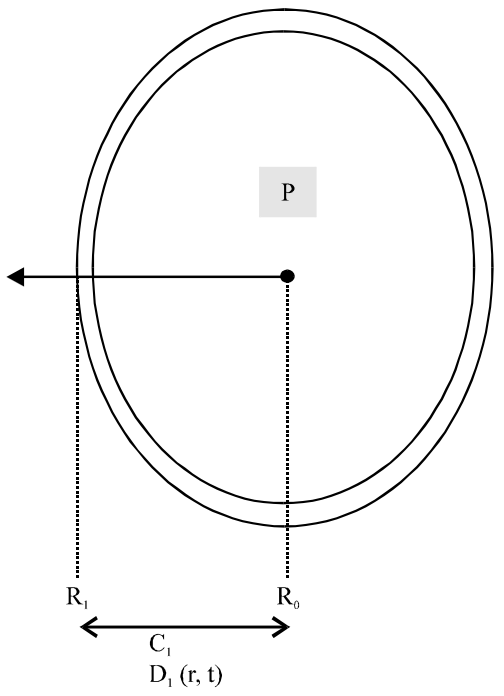

Fig. 2: Diffusion on paddy drying

$$
\begin{aligned}
& \frac{\partial \mathrm{C}}{\partial \mathrm{t}}=\mathrm{D}_{\text {eff }}\left(\frac{1}{\mathrm{r}} \frac{\partial}{\partial \mathrm{r}}\left(\mathrm{r} \frac{\partial \mathrm{C}}{\partial \mathrm{r}}\right)\right) \\
& \frac{\partial \mathrm{C}}{\partial \mathrm{t}}=\mathrm{D}_{\text {eff }} \frac{1}{\mathrm{r}}\left(\frac{\partial \mathrm{C}}{\partial \mathrm{r}}+\mathrm{r} \frac{\partial^{2} \mathrm{C}}{\partial \mathrm{r}^{2}}\right) \\
& \frac{\partial \mathrm{C}}{\partial \mathrm{t}}=\mathrm{D}_{\text {eff }}\left(\frac{\partial^{2} \mathrm{C}}{\partial \mathrm{r}^{2}}+\frac{1}{\mathrm{r}} \frac{\partial \mathrm{C}}{\partial \mathrm{r}}\right)
\end{aligned}
$$

The boundary condition was used to describe the cylindric material as follow: boundary condition in the center paddy circle, $r=R_{0}, t>0$ :

$$
\frac{\partial \mathrm{C}}{\partial \mathrm{t}}=0
$$

Boundary condition in outer layer of paddy, $r=R_{1}, t>0$ :

$$
\frac{\partial \mathrm{C}}{\partial \mathrm{t}}=\mathrm{k}\left(\mathrm{C}-\mathrm{C}_{\mathrm{E}}\right)
$$

Where:

$$
\begin{aligned}
& \mathrm{D}_{\text {eff }}=\text { The effective moisture diffusivity }\left(\mathrm{m}^{2} / \mathrm{sec}-1\right) \\
& \mathrm{r}=\text { The paddy layer } \\
& \mathrm{k}=\text { The constant rate of the drying (min- } 1)
\end{aligned}
$$

The value of $\mathrm{D}_{\text {eff }}$ and $\mathrm{k}$ were obtained by Excel Solver and validated by the average moisture content referring to experiment data. Temperature dependence of effective moisture diffusivity can be given by an Arrhenius Model, as shown in Eq. 10:

$$
D_{\text {eff }}=D_{0} e^{\left(-\frac{E a}{R T_{K}}\right)}
$$

where $\mathrm{D}_{0}$ was the pre-exponential factor of the Arrhenius equation Ea was the activation energy (kJ.mol-1) R was the universal gas constant $(0.008314 \mathrm{~kJ} . \mathrm{mol}-1 . \mathrm{K}-1)$ and $\mathrm{T}_{\mathrm{k}}$ was the absolute air temperature $(\mathrm{K})$.

\section{RESULTS AND DISCUSSION}

Effect of temperature and zeolite: The moisture ratio versus time was observed as depicted in Fig. 3. At same sampling time and operational temperature, the paddy drying with zeolite resulted lower moisture content as indicated in lower moisture ratio. With zeolite, the air was dehumidified to the low moisture content. Hence, the relative humidity of air becomes lower that enhanced driving force for drying (Djaeni et al., 2013; Utari et al., 2018). Using zeolite as air dehumidifier, the drying process has two advantages as follows: zeolite lowers the air humidity in which increases the driving force for drying and lowering air humidity increases air temperature due to the adsorption heat (Djaeni et al., 2011, 2013). With these advantages, the paddy drying can be more effective.

The proximate was observed after the completion of the drying process. The results showed that the content of fat, protein and carbohydrate were still comparable with the other drying method (Table 1). The heat sensitive compounds in paddy are protein and glucose groups. The companents can combine to form browning process (Lamberts et al., 2006). Meanwhile, the protein denaturation can be posible, especially for operating temperature above $70^{\circ} \mathrm{C}$ (Bischof and $\mathrm{He}, 2005$; Ovissipour et al., 2017). However, under low drying temperature ranging from $40-60^{\circ} \mathrm{C}$, the protein denaturation can be inhibitted. Thus, the paddy quality is still acceptable.

For all cases, the increase of temperature can also reduce the relative humidity of air. Therefore, the drying rate becomes faster or more water can be removed from the product. Beside that at higher drying temperatures, the air brings more sensible heat that can be used to evaporate water from the wet paddy. Hence, at higher operational temperature (supposed above $80^{\circ} \mathrm{C}$ ), the effect of dehumidified air is not significant (Djaeni et al., 2015). However, at higher temperature, the heat sensitive ingredients can deteriorate.

Model validation and moisture mass distribution profile: Based Fig. 3, the effective moisture diffusivity for every operational temperature was estimated using Eq. 4-9. As 
Djaeni et al., 2018; Rayaguru and Routray, 2010). Temperature dependence of moisture effective diffusivity

Table 1: Proximate analysis result

\begin{tabular}{|c|c|c|c|c|}
\hline \multirow[b]{2}{*}{ Samples } & \multicolumn{4}{|c|}{ Content $(\%)$} \\
\hline & Ash & Fat & Protein & Carbohy drate \\
\hline Zeolite $40^{\circ} \mathrm{C}$ & 11.18 & 0.73 & 6.73 & 66.83 \\
\hline Zeolite $60^{\circ} \mathrm{C}$ & 11.10 & 0.73 & 6.73 & 66.86 \\
\hline Non-zeolite $40^{\circ} \mathrm{C}$ & 11.24 & 0.71 & 6.75 & 66.80 \\
\hline Non-zeolite $60^{\circ} \mathrm{C}$ & 11.32 & 0.70 & 6.76 & 66.32 \\
\hline
\end{tabular}

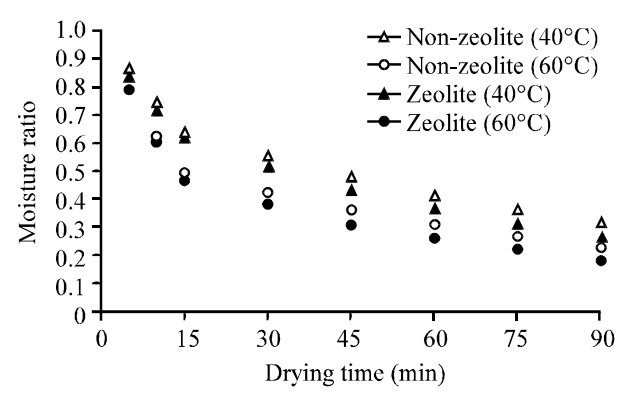

Fig. 3: Moisture content at different drying times and temperatures

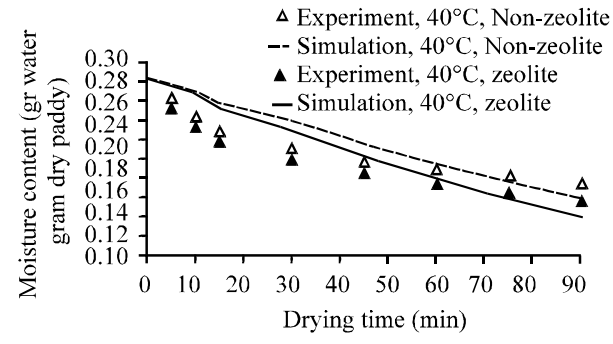

Fig. 4: Experimental and simulation moisture content at $\mathrm{T}=40^{\circ} \mathrm{C}$ was well correlated using Arrhenius equation. As the the indicators, the coefficient of determination $\left(\mathrm{R}^{2}\right)$ and Sum of the Squared Error (SSE) were evaluated. The $\mathrm{R}^{2}$ and SSE were calculated based on the different between the average moisture content estimated by model with experiment data. The average moisture content was estimated by considering the level of moisture in every paddy layer. The accurate effective moisture diffusivity was chosen when the value of $\mathrm{R}^{2}$ closes to 1.0 with low SSE value. The results were depicted in Table 2 for all drying temperature. The average mositure content in paddy obtained by model and experiment for $40^{\circ} \mathrm{C}$ are illustrated in Fig. 4 that indicate the trendline of the moisture profile are similar.

With the zeolite, the moisture diffusivity as well as constant of drying rate at the surface of paddy was higher than that of without zeolite. Hence, the drying time can be faster. Meanwhile, for all cases, the increase of temperature also resulted higher effective moisture diffusivity coefficient as well as constant of drying rate. With the increase of temperature, the movement of moisture molecules in the surface and tissue layers of paddy is accelarated. By the zeolite or increasing temperature, the relative humidity of air becomes lower. Hence, the water activity different between product and air becomes higher that can increase the water transfer from wet product to the air (Bouzenada et al., 2014; moisture diffusivity increase, the activation Energy (Ea) in drying with zeolite can be reduced. Compared with the other research results, the combination of air dehumidification and the increase of air temperature up to $60^{\circ} \mathrm{C}$ as performed in this study can find positive improvement (Golmohammadi et al., 2016; Oli et al., 2014;

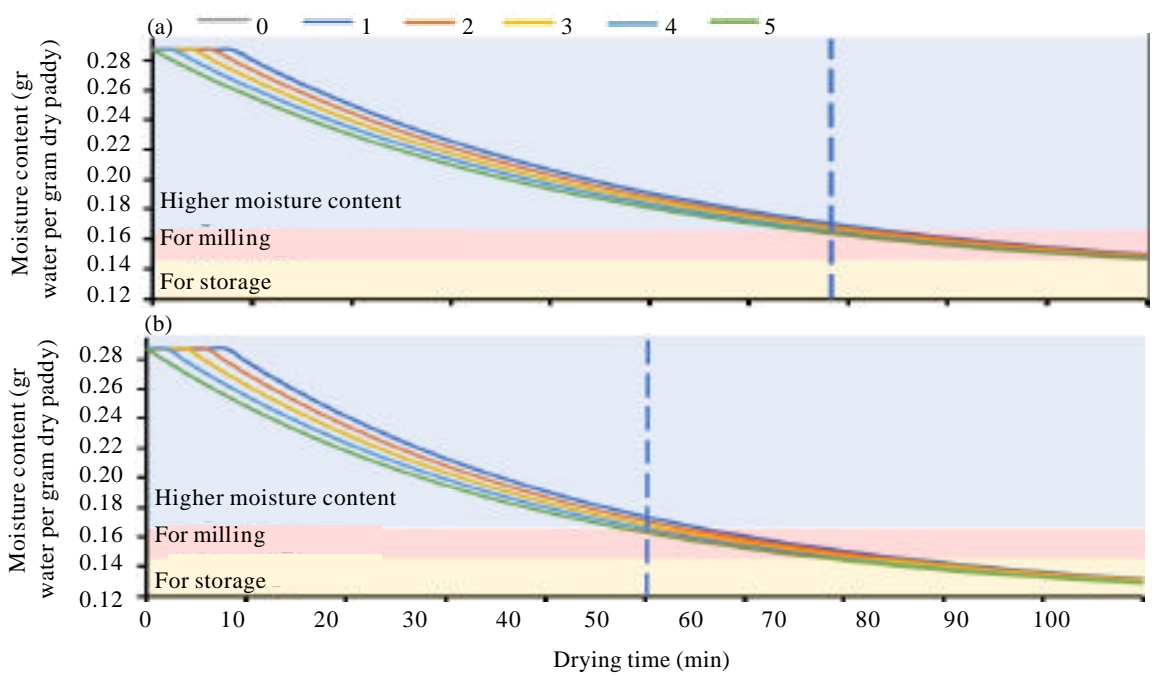

Fig. 5: Moisture mass distribution at $\mathrm{T}=40^{\circ} \mathrm{C}$ : a) Without zeolite and b) With zeolite (note number $0-5$ represent paddy layers) 


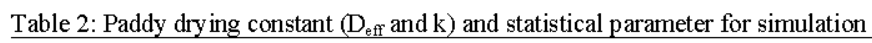

\begin{tabular}{|c|c|c|c|c|c|c|c|c|}
\hline \multirow[b]{2}{*}{ Temperature $\left({ }^{\circ} \mathrm{C}\right)$} & \multicolumn{4}{|l|}{ Non-zeolite } & \multicolumn{4}{|l|}{ Zeolite } \\
\hline & $D_{\mathrm{eff}}\left(\mathrm{m}^{2} / \mathrm{min}\right)$ & $\mathrm{k}$ & $\mathrm{R}^{2}$ & SSE & $D_{e f f}\left(m^{2} / m i n\right)$ & $\mathrm{k}$ & $\mathrm{R}^{2}$ & SSE \\
\hline 40 & $1.000 \times 10^{-8}$ & 0.022 & 0.888 & 0.003 & $7.626 \times 10^{8}$ & 0.025 & 0.897 & 0.004 \\
\hline 50 & $1.010 \times 10^{-7}$ & 0.024 & 0.832 & 0.008 & $4.881 \times 10^{-7}$ & 0.032 & 0.864 & 0.008 \\
\hline 60 & $1.000 \times 10^{6}$ & 0.031 & 0.852 & 0.011 & $1.000 \times 10^{5}$ & 0.039 & 0.856 & 0.010 \\
\hline
\end{tabular}

Tirawanichakul et al., 2014). The model with effective moisture diffusivity estimation was validated by average moisture content in paddy from experiment. The valid paramater can be used for predicting moisture level at every layer of paddy. For example, the paddy was dried at $40^{\circ} \mathrm{C}$ for $100 \mathrm{~min}$. The simulation results are expressed in Fig. 5. At first $30 \mathrm{~min}$, the moisture level in paddy layers decreased gradually corresponding to the layer position. The surface of paddy (outer layer) has lowest moisture content, since, the moisture evaporates to the air. So, the moisture moves from inside to the outer layer. In paddy drying, the process was run until average moisture content achieving $14 \%$ wet basis or 0.16 dry basis. This condition is preferable both for paddy storing or milling. In this case with the zeolite, to dry paddy from moisture content $22 \%$ up to $14 \%$ needs around $50 \mathrm{~min}$. The process was $18-20$ shorter than the drying without zeolite. This result is comparable with the other product dried with zeolite or air dehumidification (Djaeni et al., 2014; Osorio-Revilla et al., 2006; Goudra et al., 2014).

\section{CONCLUSION}

This study showed that zeolite improves the driving force for paddy drying. At same operational time and temperature, the water transferred from wet paddy is higher compared to the paddy drying without zeolite. In addition, the proximate in paddy after the drying is acceptable and still comparable with the other drying method. However, at higher drying temperatures, the relative humidity of air is also low. Therefore, the effect of the zeolite is not significant. The effective moisture difussivity has been also predicted. Result showed that the effective moisture diffusivity of paddy dried with zeolite was higher than that of without zeolite. The model also can fit with the experiment and be able to describe the moisture distribution accurately.

\section{REFERENCES}

Bird, R.B., W.E. Stewart and E.N. Lightfoot, 2007. Transport Phenomena. 2nd Edn., John Wiley and Sons, New York.

Bischof, J.C. and X. He, 2005. Thermal stability of proteins. Ann. N.Y. Acad. Sci., 1066: 12-33.
Bouzenada, S., A.N. Kaabi, L. Fraikin and A. Leonard, 2014. Experimental study on dehumidification/ regeneration of liquid desiccant: $\mathrm{LiBr}$ solution. Procedia Comput. Sci., 32: 673-680.

Djaeni, M., A.C. Kumoro, S.B. Sasongko and F.D. Utari, 2018. Drying rate and product quality evaluation of roselle (Hibiscus sabdariffa L.) calyces extract dried with foaming agent under different temperatures. Intl. J. Food Sci., 2018: 1-8.

Djaeni, M., C.J. Van Asselt, P.V. Bartels, J.P.M. Sanders and G. van Straten et al., 2011. Low temperature drying with air dehumidified by Zeolite for food products: Energy efficiency aspect analysis. Intl. J. Food Eng., 7: 1-25.

Djaeni, M., D. Anggoro, G.W. Santoso, D. Agustina and N. Asiah et al., 2014. Enhancing the food product drying with air dehumidified by Zeolite. Adv. J. Food Sci. Technol., 6: 833-838.

Djaeni, M., D. Ayuningtyas, N. Asiah, H. Hargono and R. Ratnawati et al., 2013. Paddy drying in mixed adsorption dryer with Zeolite: Drying rate and time estimation. Reaktor, 14: 173-178.

Djaeni, M., N. Asiah, S. Suherman, A. Sutanto and A. Nurhasanah, 2015. Energy efficient dryer with rice husk fuel for agriculture drying. Intl. J. Renewable Energy Dev., 4: 20-24.

Erbay, Z. F. Icier, 2010. A review of thin layer drying of foods: Theory, modeling and experimental results. Crit. Rev. Food Sci. Nutr., 50: 441-464.

Golmohammadi, M., M. Foroughi-dahr, M.R. Hamaneh, A.R. Shojamoradi and S.J. Hashemi, 2016. Study on drying kinetics of paddy rice: Intermittent drying. Iran. J. Chem. Chem. Eng., 35: 105-117.

Goudra, P.G., C.T. Ramachandra and N. Udaykumar, 2014. Dehydration of onions with different drying methods. Curr. Trends Technol. Sci., 3: 210-216.

Gunhan, T., V. Demir, E. Hancioglu and A. Hepbasli, 2005. Mathematical modelling of drying bay leaves. Energy Convers. Manage., 46: 1667-1679.

Kiranoudis, C.T., Z.B. Maroulis and D. Marinos-Kouris, 1996. Drying of solids: Selection of some continuous operation dryer types. Comput. Chem. Eng., 20: S177-S182. 
Lamberts, L., K. Brijs, R. Mohamed, N. Verhelst and J.A. Delcour, 2006. Impact of browning reactions and bran pigments on color of parboiled rice. J. Agric. Food Chem., 54: 9924-9929.

Laohavanich, J. and S. Wongpichet, 2008. Thin layer drying model for gas-fired infrared drying of paddy. Songklanakarin J. Sci. Technol., 30: 343-348.

Manikantan, M.R., P. Barnwal and R.K. Goyal, 2014. Drying characteristics of paddy in an integrated dryer. J. Food Sci. Technol., 51: 813-819.

Morrison, D.M., L. Chester, C.A.N. Samuels and D.R. Ledoux, 2016. The determination of aflatoxins in paddy and milled fractions of rice in Guyana: Preliminary results. Intl. J. Biol. Biomol. Agric. Food Biotechnol. Eng., 10: 721-725.

Nguyen, V.H., T.H. Duong and M. Gummert, 2016. Building a model for the paddy columnar dryer and analyzing a reverse-airflow approach to achieve uniform grain temperature. Intl. Agric. Eng. J., 25: 64-73.

Oli, P., R. Ward, B. Adhikari and P. Torley, 2014. The diffusion of moisture in paddy during hydration and dehydration processes. Drying Technol. Intl. J., 32: 1423-1434.

Omid, M., A.R. Yadollahinia and S. Rafiee, 2006. A thin-layer drying model for paddy dryer. Proceedings of the International Conference on Innovations in Food and Bioprocess Technologies, December 12-14, 2006, AIT, Pathumthani, Thailand, pp: 202-211.
Osorio-Revilla, G., T. Gallardo-Velazquez, S. Lopez-Cortes and S. Arellano-Cardenas, 2006. Immersion drying of wheat using Al-PILC, Zeolite, clay and sand as particulate media. Drying Technol., 24: 1033-1038.

Ovissipour, M., B. Rasco, J. Tang and S. Sablani, 2017. Kinetics of protein degradation and physical changes in thermally processed Atlantic salmon (Salmo salar). Food Bioprocess Technol., 10: $1865-1882$.

Rayaguru, K. and W. Routray, 2010. Effect of drying conditions on drying kinetics and quality of aromatic andanus amaryllifolius leaves. J. Food Sci. Technol., 47: 668-673.

Thompson, T.L., R.M. Peart and G.H. Foster, 1986. Mathematical simulation of corn drying: A new model. Trans. ASAE, 11: 582-586.

Tirawanichakul, S., S. Wanthong and Y. Tirawanichakul, 2014. Effective moisture diffusivity, moisture sorption, thermo-physical properties and infrared drying kinetics of germinated paddy. Songklanakarin J. Sci. Technol., 36: 115-124.

Utari, F.D., M. Djaeni and F. Irfandy, 2018. Constant rate of paddy rice drying using air dehumidification with zeolite. IOP Conf. Ser. Earth Environ. Sci., 102: 1-9. 